\title{
Environmental and compositional correlates of growth rate in deep-water bamboo corals (Gorgonacea; Isididae)
}

\author{
Ronald E. Thresher* \\ CSIRO Marine and Atmospheric Research and Wealth from Oceans and Climate Adaptation Flagships, \\ GPO Box 1538, Hobart, Tasmania, Australia
}

\begin{abstract}
Little is known about the factors that affect the growth rates of deep-water corals. Analysis of 23 specimens of bamboo corals, a ubiquitous deep-water group, that were reliably aged using radiometric techniques or validated increment counts indicates that the radial growth rate of the coral's calcite internode declines with depth and increases logistically with ambient temperature. Temperature alone accounts for about half of the variance among specimens in lifetime mean growth rates. Growth rates plateau below $2^{\circ} \mathrm{C}$ and above $5^{\circ} \mathrm{C}$, which likely reflects physiological constraints on growth and calcification. Thus far, the only other effect on growth rate identified is a tendency for colonies from the NE Pacific to grow faster relative to ambient temperature than colonies in other regions. Analysis of elemental composition of the calcite internode, based on data available for 16 of the 23 specimens, shows that, contrary to suggestions in the literature, growth rate does not correlate with Sr/Ca ratios, neither among or within colonies. Rather, within-colony ontogenetic variability in increment width, an index of short-term growth rate, correlates positively with calcium weight-fractions and negatively with the ratio between $\mathrm{P}$ and $\mathrm{S}$, an index of organic content. The underlying mechanism is likely to be a link between crystal ultrastructure, which varies with growth rate, and the ratio between $\mathrm{CaCO}_{3}$ and organic matrix in different crystal types. Between colonies, composition correlates poorly with growth rate. This could reflect spatial and temporal heterogeneity in other environmental factors that determine internode composition, as well as difficulties in standardising P measurements across specimens.
\end{abstract}

KEY WORDS: Age $\cdot$ Calcite $\cdot$ Depth $\cdot$ Phosphorus $\cdot$ Skeletal composition $\cdot$ Sulphur $\cdot$ Temperature $\cdot$ Ultrastructure

Resale or republication not permitted without written consent of the publisher

\section{INTRODUCTION}

Gorgonians are a major component of the benthic fauna of both shallow and deep-water rocky habitats and coral reefs. They may also be very long-lived recorders of deep-water oceanography (Heikoop et al. 2002, Thresher et al. 2004). However, information on the ecology of deep-water species is very sparse, limited largely to notes on depth distribution and general biotic associations (Andrews et al. 2002, Krieger \& Wing 2002, Freiwald \& Roberts 2005, Roberts et al. 2009) and, more recently, age and growth rates. The latter have been determined using a variety of techniques, ranging from counting assumed annual growth increments to assays of time-dependent changes in biochemistry and radiogenic isotopes (Roark et al. 2005, Sherwood et al. 2006, Andrews et al. 2007, Tracey et al. 2007). All indicate that deep-water gorgonians are slow-growing and long-lived, in some cases reaching ages of several hundred years.

Data also indicate substantial variability in growth rates, even within closely allied taxa. In the bamboo corals (Gorgonacea; Isididae), so-called because their alternating black organic nodes and white calcite 
internodes resemble bamboo canes, radial growth rates for the internodes have been reported from as little as 12 to as much as $169 \mu \mathrm{m} \mathrm{yr}^{-1}$ (see Table 1). The ecological significance of this range is not known. It has also been speculated that variability in growth rate is reflected in the elemental composition of the gorgonian's calcite skeleton. Weinbauer et al. (2000) noted that strontium/calcium (Sr/Ca) ratios in Corallium rubrum correlated with intra-colony differences in growth rate. Roark et al. (2005) subsequently suggested that periodicity in $\mathrm{Sr} / \mathrm{Ca}$ ratios in North Pacific bamboo corals reflected seasonal cycles in surface productivity via effects on growth. If validated, an elemental marker for growth rate in gorgonians would be a valuable proxy for ecological, paleoecological and paleoclimatic studies.

In the present study, I compile data from the literature and work in progress on the growth rates of 23 specimens of bamboo coral worldwide to test for general correlates of growth rate in the family. Calcite composition has been analysed for 16 of these specimens, mostly from the SW Pacific. I use these data to test the hypothesis that differences in growth rate within and among specimens correlate with the composition of the internode.

\section{MATERIALS AND METHODS}

Details of bamboo coral specimens for which data are available are given in Table 1. Only Sherwood \& Edinger (2009) identified their specimens to species level (Keratoisis ornata), reflecting general uncertainty in isidid taxonomy (France 2007). Where it was not specified in the source material, mean radial growth rate of the internode was calculated based on the age (or mean age if a range was given) of the coral and mean radius of the internode at the point where age was determined. Reported collection depths vary from a specific depth (typically for specimens collected by submersible) to a depth range or an estimated depth where the specimen was obtained by trawling. Correlations are based on the mean depth when a range was given. The available samples span a depth range of nearly $2 \mathrm{~km}$ (601 to $2350 \mathrm{~m}$ ). Water temperature at collection location is from the original source when available (e.g. Roark et al. 2005, O. Sherwood pers. comm.) or is a long-term mean estimated from oceanographic databases (primarily the CSIRO Atlas of Regional Seas, CARS; see Ridgway et al. 2002, www.marine.csiro.au/ dunn/cars2006/). The estimate is subject to possible bias due to uneven seasonal sampling, but this bias

Table 1. Details for specimens included in growth rate analyses. ID is the identifier from the original source. Roark et al. (2005) did not specify genus. NZ: New Zealand; Aust: SE Australia; G of A: Gulf of Alaska; Cal: California; NF \& L: Newfoundland and Labrador; Ant: Antarctica. SWPAC: southwest Pacific; NEPAC: northeast Pacific; NWATL: northwest Atlantic; ANT: Antarctic. Unless specified in the original source, growth rate is radius of the internode divided by mean estimated age. Aging methods: $1=$ increment counts; $2=\mathrm{Pb}-\mathrm{Ra} ; 3=\mathrm{U}-\mathrm{Th} ; 4={ }^{14} \mathrm{C} ; 5=$ environmental matching. Temperatures are from or estimated from the original source, or otherwise from the CSIRO Atlas of Regional Seas database

\begin{tabular}{|c|c|c|c|c|c|c|c|c|c|}
\hline ID & Genus & Location & Region & $\begin{array}{c}\text { Internode } \\
\text { radial growth } \\
\text { rate }\left(\mu \mathrm{m} \mathrm{yr}^{-1}\right)\end{array}$ & $\begin{array}{l}\text { Aging } \\
\text { method }\end{array}$ & $\begin{array}{l}\text { Collection } \\
\text { depth } \\
\text { (m) }\end{array}$ & $\begin{array}{c}\mathrm{T} \text { at } \\
\text { depth } \\
\left({ }^{\circ} \mathrm{C}\right)\end{array}$ & $\begin{array}{c}\text { Calcite } \\
\text { analysed }\end{array}$ & Source \\
\hline Z9583 & Keratoisis & NZ & SWPAC & 49.6 & 1 & $935-1043$ & 4.94 & $\mathrm{Y}$ & Tracey et al. (2007) \\
\hline Z10909 & Lepidisis & NZ & SWPAC & 168.9 & 1 & $638-840$ & 6.67 & $\mathrm{Y}$ & Tracey et al. (2007) \\
\hline Z11101 & Lepidisis & NZ & SWPAC & 154.2 & 1 & $874-1030$ & 5.39 & Y & Tracey et al. (2007) \\
\hline Z9225 & Lepidisis & NZ & SWPAC & 167.4 & 1,2 & $690-800$ & 6.96 & $\mathrm{Y}$ & Tracey et al. (2007) \\
\hline K2 & Keratoisis & Aust & SWPAC & 103.8 & $1-5$ & 1000 & 4.66 & Y & Thresher et al. (2007) \\
\hline K1 & Keratoisis & Aust & SWPAC & 133.3 & $1,4,5$ & 1000 & 4.66 & $\mathrm{Y}$ & Thresher et al. (2007) \\
\hline ALV3808\#3 & Isidid & $\mathrm{G}$ of $\mathrm{A}$ & NEPAC & 120.0 & 1,4 & 720 & 3.00 & Sr only & Roark et al. (2005) \\
\hline ALV3808\#4 & Isidid & $\mathrm{G}$ of $\mathrm{A}$ & NEPAC & 89.0 & 4 & 704 & 3.40 & $\mathrm{~N}$ & Roark et al. (2005) \\
\hline ALV3808\#5 & Isidid & $\mathrm{G}$ of $\mathrm{A}$ & NEPAC & 90.1 & 4 & 634 & 3.50 & $\mathrm{~N}$ & Roark et al. (2005) \\
\hline Is 3 & Isidella & Aust & SWPAC & 77.0 & 4,5 & $1100-1200$ & 3.70 & $\mathrm{Y}$ & Thresher et al. (2009) \\
\hline L2 & Lepidisis & Aust & SWPAC & 118.0 & 4 & $881-1154$ & 4.54 & $\mathrm{Y}$ & Thresher et al. (2009) \\
\hline T948-A2 & Keratoisis & Cal & NEPAC & 63.2 & 2 & 1574 & 2.60 & $\mathrm{~N}$ & Andrews et al. (2007) \\
\hline Is 4 & Isidella & Aust & SWPAC & 98.3 & 4,5 & $1050-1230$ & 3.75 & $\mathrm{Y}$ & Sherwood et al. (2009) \\
\hline L4 & Lepidisis & Aust & SWPAC & 38.0 & 4,5 & $1050-1230$ & 3.75 & $\mathrm{Y}$ & Sherwood et al. (2009) \\
\hline TH17442 & Lepidisis & Aust & SWPAC & 40.0 & 4 & $900-1100$ & 4.66 & $\mathrm{Y}$ & Sherwood et al. (2009) \\
\hline T428-A10 & Keratoisis & Cal & NEPAC & 41.0 & 2 & 1455 & 2.50 & $\mathrm{~N}$ & Andrews et al. (2007) \\
\hline 2452 & Keratoisis & NF \& L & NWATL & 74.0 & 4 & 601 & 4.36 & $\mathrm{~N}$ & Sherwood \& Edinger (2009) \\
\hline 1449 & Keratoisis & NF \& L & NWATL & 75.0 & 4 & 1193 & 3.37 & $\mathrm{~N}$ & Sherwood \& Edinger (2009) \\
\hline 1343 & Keratoisis & NF \& L & NWATL & 53.0 & 4 & 713 & 4.00 & $\mathrm{~N}$ & Sherwood \& Edinger (2009) \\
\hline L8 & Lepidisis & Aust & SWPAC & 76.8 & 5 & 1000 & 4.58 & $\mathrm{Y}$ & Thresher et al. (unpubl. data) \\
\hline K8 & Keratoisis & Aust & SWPAC & 15.4 & 4 & 2000 & 2.40 & $\mathrm{Y}$ & Neil et al. (unpubl. data) \\
\hline E2 & Echinisis & Ant & ANT & 12.0 & 4,5 & 699 & 0.5 & $\mathrm{Y}$ & Thresher et al. (unpubl. data) \\
\hline K22 & Keratoisis & Ant & ANT & 15.5 & 4,5 & $2119-2592$ & -0.4 & $\mathrm{Y}$ & Thresher et al. (unpubl. data) \\
\hline
\end{tabular}


was assumed to be minor relative to long-term differences among sites. At the sampled depths, reported annual ranges in temperature vary from just over $1{ }^{\circ} \mathrm{C}$ in the SW Pacific (Thresher et al. 2004) to $<0.5^{\circ} \mathrm{C}$ in the NE Pacific (Roark et al. 2005) and Antarctic (Thresher et al. unpubl. data). Long-term means differ among sites by more than $7^{\circ} \mathrm{C}\left(-0.4\right.$ to $\left.6.96^{\circ} \mathrm{C}\right)$.

$\mathrm{Sr} / \mathrm{Ca}$ ratios are provided for one specimen by Roark et al. (2005). Otherwise, data on magnesium (Mg), Sr, phosphorus (P), sulphur (S) and calcium (Ca) weightfractions are from Thresher et al. (2004, 2007, 2009, unpubl. data). For the latter studies, internode composition was measured using a JXA8900R electron probe microanalyser. Procedures are detailed in Thresher et al. (2007) and follow closely those developed by Gunn et al. (1992). In most specimens, element weightfractions were determined at $100 \mu \mathrm{m}$ intervals (beam spot center-to-center) from each coral's central pore to its outer margin, using a circular $50 \mathrm{nA}$ beam accelerated at $15 \mathrm{kV}$ and defocused to $50 \mu \mathrm{m}$. Because of their size, a few of the smaller specimens were measured at higher resolution (5 $\mu \mathrm{m}$ spot size, edge-to-edge). For these, the slight effect of the higher beam power density used on element weight-fractions was compensated for following Thresher et al. (2007). In general, the measured concentrations of all 5 elements are similar to those in other biogenic calcites, average more than 10 times higher than their respective minimum detection limits and were measured with an instrumental accuracy of about 2 to $5 \%$, depending on the element. Issues of data quality and reproducibility using electron probe microanalysis in isidids are considered in detail by Thresher et al. (2007).

To assess the relationships between composition and growth rate within coral colonies, I measured increment widths in 2 large specimens of Keratoisis (K1 and K2) collected in the SW Pacific and described in Thresher et al. (2004). Increment widths were measured across thin sections taken near the base of each coral, adjacent to the section used for probe microanalysis. Internode growth increments are depicted by Roark et al. (2005) and Tracey et al. (2007); their ultrastructure is detailed by Noe \& Dullo (2006). Measurements were made under transmitted light using a photomicrometer on a Wild stereomicroscope, and were repeated using 2 randomly chosen radii in each of the 2 corals to test for reproducibility. Increments close to the center of K2, consisting of about $10 \%$ of the total radius, could not be resolved well enough for measurement; there was less trouble measuring near the center in $\mathrm{K} 1$, except for a small region directly at the core (see Noe \& Dullo 2006). Because the measurements were done on different sections of the corals, the relationship between the positions of the measured radii and probe microanalysis lines on the same specimens is not known.
Radiocarbon age determination of K2 was done using $1 \mathrm{~mm}$ increments, cut using a Dremel tool from a $2 \mathrm{~mm}$ wide and $2 \mathrm{~mm}$ thick strip of calcite from the center to the edge of its internode. The calcite samples were combusted in individual quartz tubes and reduced to graphite in the presence of iron catalyst, following Vogel et al. (1987). Measurements were performed on graphite targets at the Australian National University SSAMS facility. Results include a background and $\delta^{13} \mathrm{C}$ correction and are reported as $\delta^{14} \mathrm{C}$ $( \pm \mathrm{SD})$. Radiocarbon dating followed methods reported in Sherwood et al. (in press), assuming a constant reservoir age.

Statistical analyses were done using Statview and JMP. To test correlations between data sampled at different frequencies or spacing (e.g. comparing radii of unequal length), the higher density data set was slightly smoothed using a 3-point running mean and then resampled at a frequency or spacing equal to that of the lower density set.

\section{RESULTS}

\section{Environmental correlates of growth rate}

Colony mean growth rates across the 23 specimens did not correlate with the radius of the coral $(\mathrm{r}=0.29$, $\mathrm{p}=0.23$ ) (Fig. 1A) or their ages $(r=0.31, p=0.18)$ (Fig. 1B), suggesting that subsequent analyses were minimally affected by size- or age-specific changes in growth rate. Among specimens, growth was slower in corals collected in deeper water $(\mathrm{r}=0.50, \mathrm{p}<0.02)$ (Fig. 1C) and increased with ambient temperature $(\mathrm{r}=$ 0.77, $\mathrm{p}<0.001$ ) (Fig. 1D). In a step-down multiple regression of depth, temperature and colony age against growth rate, only temperature was retained as a significant correlate.

Visual inspection of the scatterplot between temperature and growth rate suggests that a linear relationship between the two, although significant, is not biologically realistic (Fig. 1D). At ambient temperatures below about $2^{\circ} \mathrm{C}$, growth rates appear to reach a minimum value of 10 to $15 \mu \mathrm{m} \mathrm{yr}{ }^{-1}$ irrespective of temperature, whereas at temperatures higher than about $5^{\circ} \mathrm{C}$, growth rates appear to plateau at a maximum of

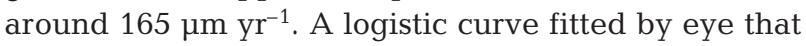
appears to capture the relationship is:

$$
\text { Radial GR }=\left[160 /\left(1+\mathrm{e}^{(5.84-1.44 \mathrm{~T})}\right)\right]+15 \times \mathrm{R}^{2}=0.51
$$

where growth rate (GR) is in $\mu \mathrm{m} \mathrm{yr}^{-1}$, T is annual mean temperature in ${ }^{\circ} \mathrm{C}$ and the applicable temperature range is -0.4 to $+6.96^{\circ} \mathrm{C}$. The upper and lower asymptotes for growth rate are 160 and $15 \mu_{\mathrm{m} \mathrm{yr}}^{-1}$, respectively, and 5.84 and 1.44 are fitting constants. $\mathrm{R}^{2}$ was 

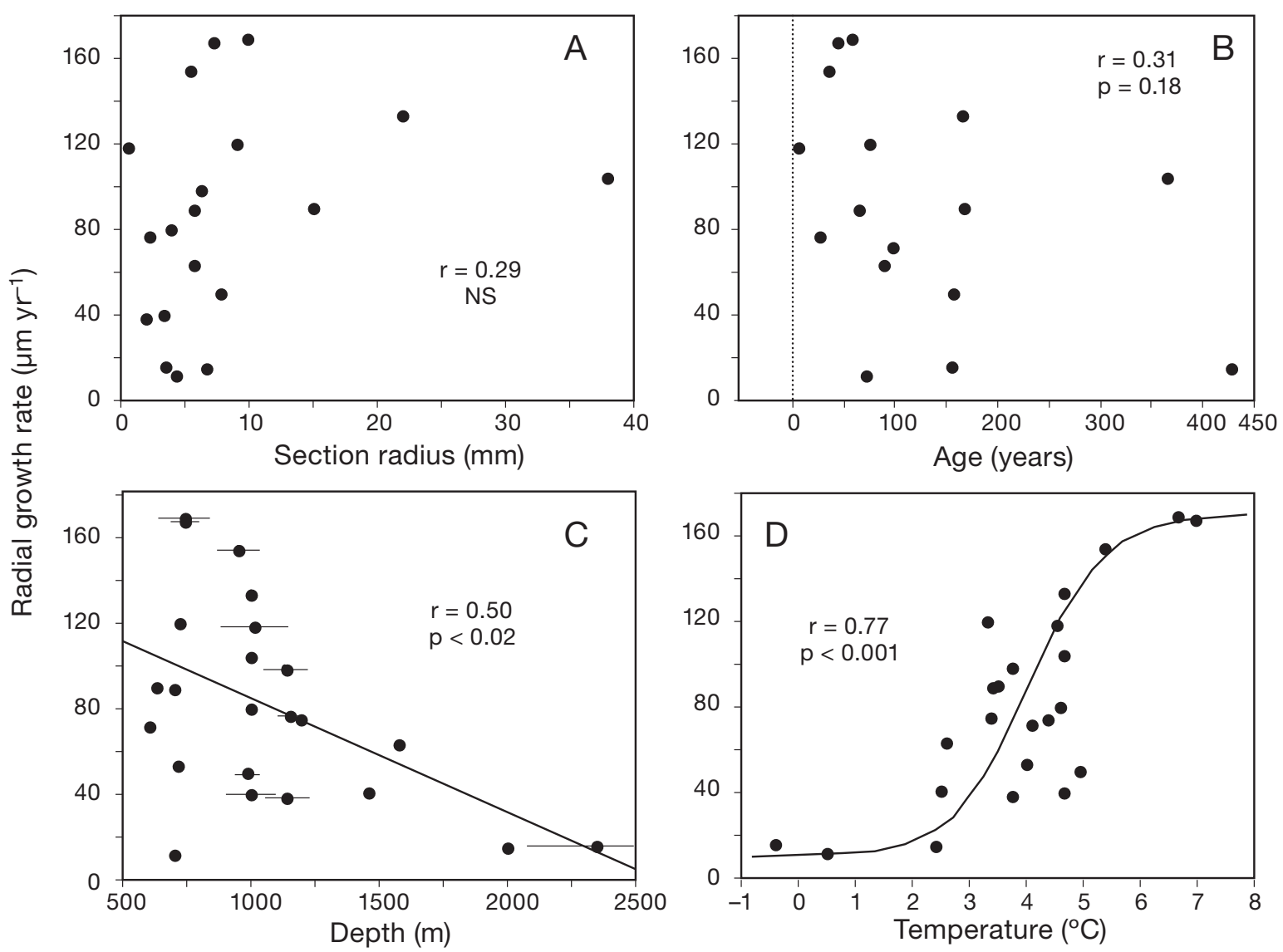

Fig. 1. Internode growth (see Table 1) against (A) internode radius, (B) estimated coral age, (C) collection depth and (D) annual mean temperature at collection depth and location for 23 specimens of bamboo coral. Sample sizes for (A) and (B) are fewer than for (C) and (D), as literature sources for a few corals supplied growth rate, but neither radius of the section or total age of the specimen. Horizontal lines in (C) indicate the range of depths over which a sample could have been collected, where given by the original source

determined by regressing observed against predicted growth rate.

Sample sizes are small, but thus far differences in growth rate between genera and between regions (SW Pacific, NE Pacific, NW Atlantic, Antarctic), unadjusted for temperature effects, were not significant (ANOVA, $F_{2,16}=2.31, \mathrm{p}=0.12$ and $F_{3,19}=2.23$, $\mathrm{p}=0.11$, respectively). However, ANCOVA indicates there was a weak effect of region on observed growth rates $\left(F_{3,19}=2.10, \mathrm{p}<0.15\right)$ (Fig. 2A) after effects of temperature were accounted for. Pairwise comparisons of the residuals (Fisher's protected least significant difference) indicate that the main outlier is the NE Pacific (differences with the NW Atlantic, SW Pacific and Antarctic significant at $p<0.05,0.06$ and 0.1 , respectively). NE Pacific specimens tended grow faster than predicted by temperature alone. In a parallel analysis, differences among genera were not significant after adjusting for effects of temperature $\left(F_{2,18}\right.$ $=0.6, \mathrm{p}=0.52)$ (Fig. 2B).

\section{Compositional correlates of growth rate}

Among specimens, lifetime mean radial growth rates were not conspicuously related to specimen-mean $\mathrm{Sr} / \mathrm{Ca}, \mathrm{P} / \mathrm{Ca}, \mathrm{S} / \mathrm{Ca}$ or $\mathrm{Mg} / \mathrm{Ca}$ ratios $(\mathrm{r}<0.2, \mathrm{p}>0.4$ in all cases) (Fig. 3A-D). To test for more complex interactions between environmental factors, growth rate and composition, the metal/Ca ratios were regressed against collection depth, temperature, age and growth rate in a step-down multiple regression. Analysis was limited to the 13 specimens collected in the SW Pacific, to avoid potentially confounding effects of regional differences in water mass characteristics. In practice, including the 3 additional specimens for which elemental data were available tended to weaken correlations but not qualitatively change the results. Intercolony differences in growth rate were not a significant correlate of any metal/Ca ratio, alone or in combination with any other variable. However, Sr/Ca ratios in the 13 specimens correlated significantly and nega- 


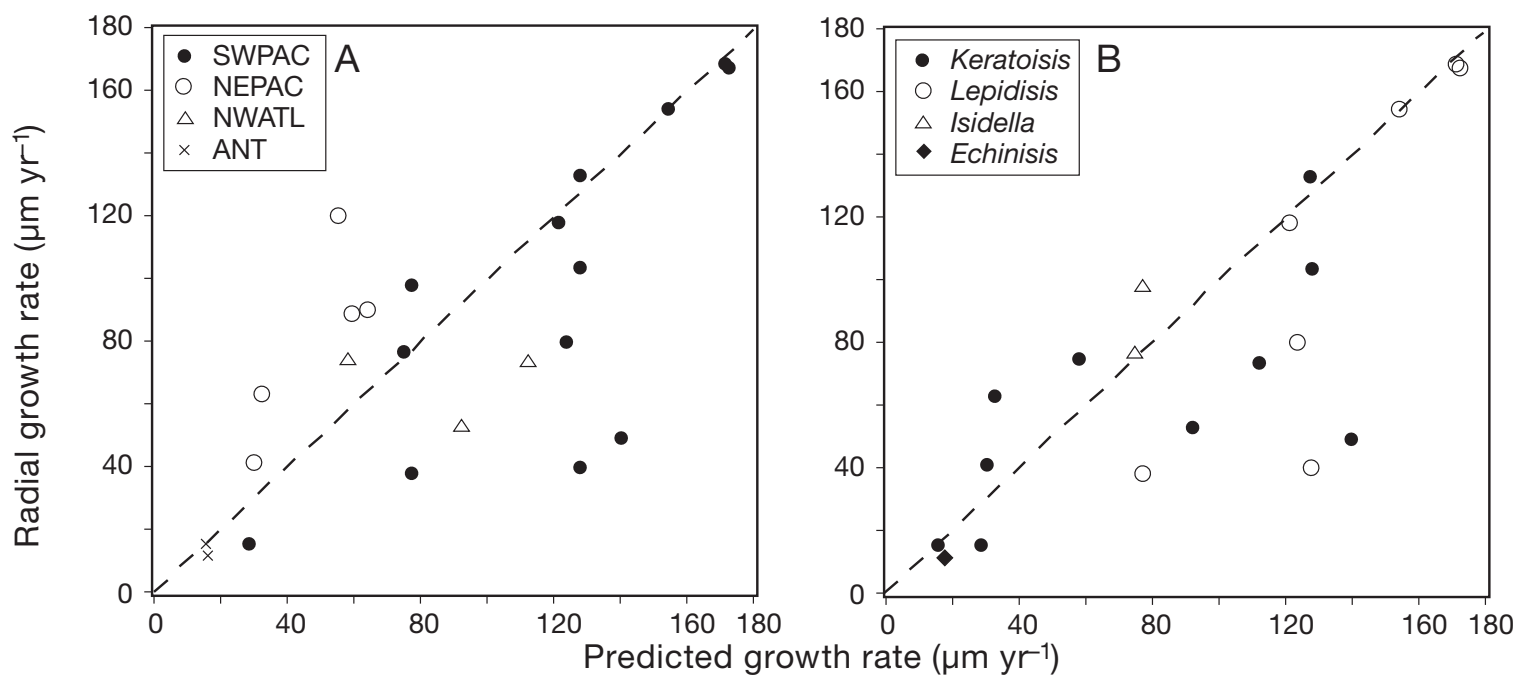

Fig. 2. Bamboo coral growth rate as predicted from ambient temperature using the logistic regression (Fig. 1D) and observed internode growth rate, split by (A) region and (B) genus. SWPAC: southwest Pacific; NEPAC: northeast Pacific; NWATL: northwest Atlantic; ANT: Antarctic

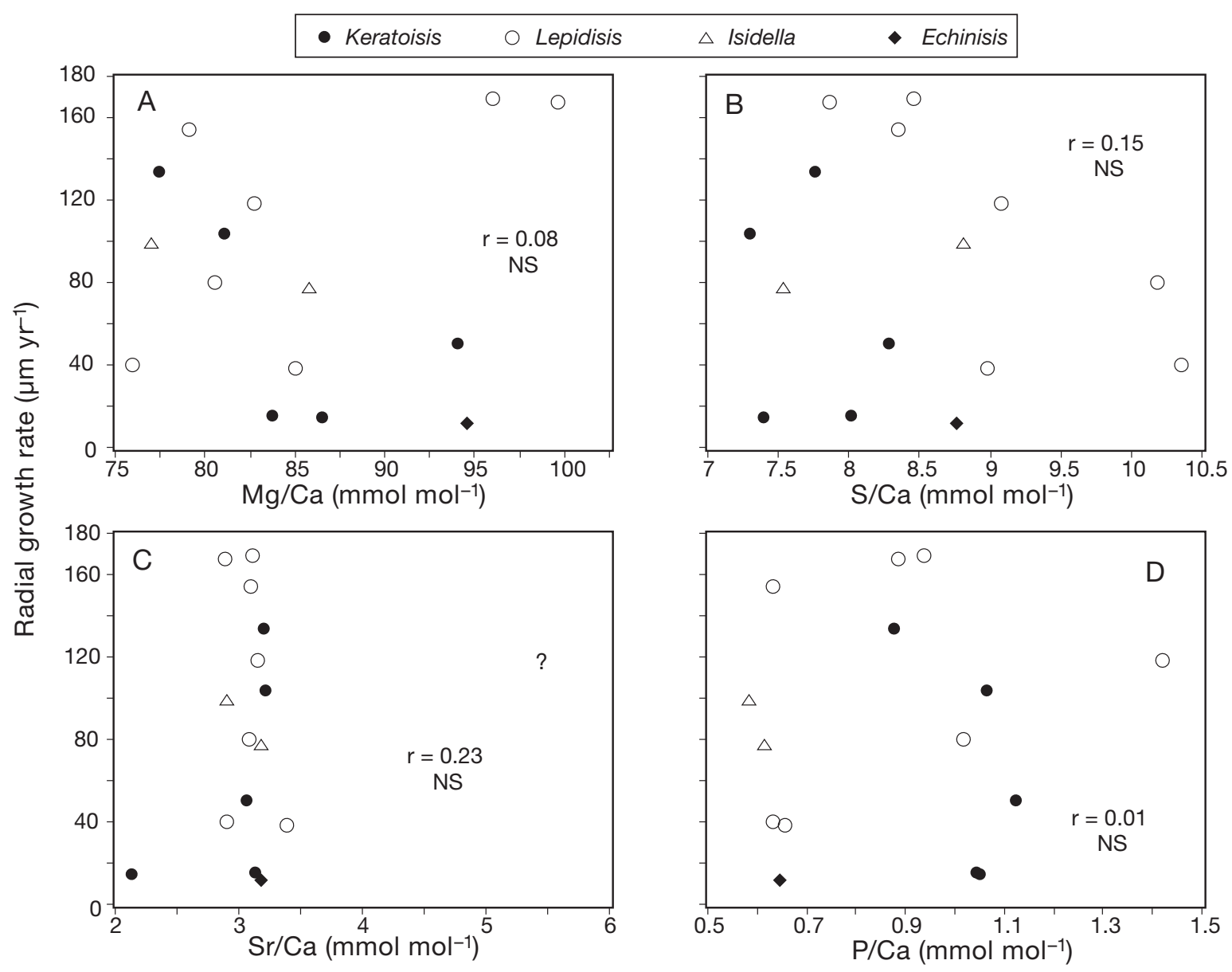

Fig. 3. Internode growth against colony mean $\mathrm{Mg} / \mathrm{Ca}, \mathrm{Sr} / \mathrm{Ca}, \mathrm{S} / \mathrm{Ca}$ and $\mathrm{P} / \mathrm{Ca}$ ratios, split by genus, for 15 specimens of bamboo coral (16 for Sr/Ca). The question mark in the Sr/Ca plot indicates a specimen not identified to the genus level. Most specimens are from the SW Pacific. NS: not significant 
tively with the combination of depth and temperature $(p=0.001$ and 0.0034 , respectively), which jointly accounted for $82 \%$ of the variance among specimens. Temperature and depth also combined to account for $48 \%$ of the variance among specimens in $\mathrm{Mg} / \mathrm{Ca}$ ratios (multiple regression, $\mathrm{p}<0.05$ ), but only the contribution of temperature was significant $(p<0.02)$. The depth effect was not quite significant $(p=0.07)$. The relationship between both variables and $\mathrm{Mg} / \mathrm{Ca}$ was positive.

An alternative growth rate metric is the amount of $\mathrm{Ca}$ and organic material in the corals. Ultrastructural studies of both isidid internodes (Noe \& Dullo 2006) and other biogenic carbonates (e.g. Casselman 1982, Mugiya 1987) show that fast and slow growth regions differ in crystal structure and, correspondingly, in the relative amounts of $\mathrm{CaCO}_{3}$ and organic matrices. Hence corals growing at different rates may differ in colony mean $\mathrm{Ca}$ and organic weight-fractions. $\mathrm{Ca}$ is measured directly using the electron microprobe. I used an indirect metric to quantify the amount of organic tissue in the coral. Thresher et al. (unpubl. data) measured the abundance of 40 elements in the EDTAsoluble (mainly calcite) and EDTA-insoluble (wholly organic) components of isidid internodes. Among the elements assayable using the electron microprobe, P/S ratios were an order of magnitude higher in the insoluble organic fraction than in the principally inorganic EDTA-soluble fraction (mol ratio $\pm \mathrm{SD}=0.467 \pm 0.118$ vs. $0.058 \pm 0.013, \mathrm{n}=8$ samples from each of 7 colonies). Ratios measured using the electron microprobe were variable and intermediate between the two, indicating the probe is measuring at least in part the relative contribution of the 2 end-members at each assay point. As such, it hypothetically constitutes an index of the relative amount of organic tissue in the internode.
The correlations between colony mean radial growth rate and both $\mathrm{Ca}$ weight-fractions and $\mathrm{P} / \mathrm{S}$ ratios are shown in Fig. 4. Neither correlation is significant, nor is the predicted negative correlation between Ca weightfraction and colony mean P/S ratio significant. When multiply regressed against age, collection depth, ambient temperature and growth rate, Ca weight-fractions for the SW Pacific specimens correlate weakly $\left(F_{2,10}=\right.$ $2.47, \mathrm{p}<0.15)$ with a combination of depth and growth rate $(\mathrm{p}<0.07$ for each variable, both correlations positive). In a parallel analysis, the only near-significant trend for $\mathrm{P} / \mathrm{S}$ ratio is a positive correlation with colony age $\left(F_{1,11}=4.14, \mathrm{p}<0.07\right)$.

To test whether metal/Ca ratios, Ca weight-fractions or $\mathrm{P} / \mathrm{S}$ ratios reflect variations in growth rates within colonies, I compared ontogenetic variability of each parameter with changes in increment width along the radial axes of 2 large, apparently conspecific specimens of Keratoisis (K1 and K2). The assumption that increment width is a measure of short-term growth rate is consistent with observations in other marine calcifying organisms, including shallow water gorgonians (Grigg 1974), and tested below. Increment widths measured along 2 different radii in K1 and K2 correlate significantly, but weakly, in both specimens (K1: $\mathrm{r}=0.11$, $\mathrm{p}<0.05 ; \mathrm{K} 2: \mathrm{r}=0.1, \mathrm{p}=0.07$ ), reflecting high levels of small-scale variability, but also similar large-scale trends along both radii (Fig. 5A,B). These trends were extracted by averaging the 2 transects for each specimen.

To test the assumption that increment widths reflect growth rates, I compared the trend line in $\mathrm{K} 2$ with growth rate variability as assayed by a series of ${ }^{14} \mathrm{C}$ age determinations made at $1 \mathrm{~mm}$ intervals across the coral's internode. The age estimates for K2 (Fig. 5C) are consistent with the ${ }^{14} \mathrm{C}$ reservoir age
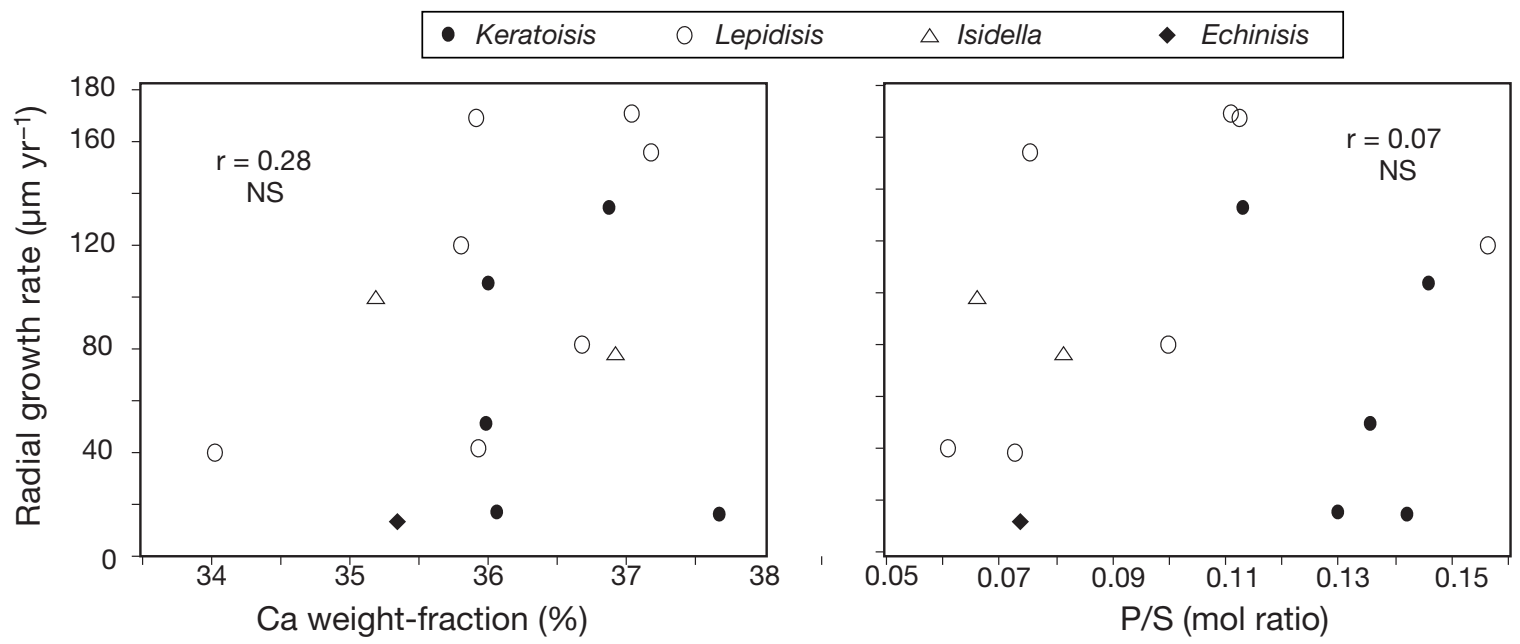

Fig. 4. Internode growth against colony mean (A) absolute Ca weight-fractions and (B) P/S ratios, split by genus, for 15 specimens of bamboo coral. Most specimens are from the SW Pacific. NS: not significant 

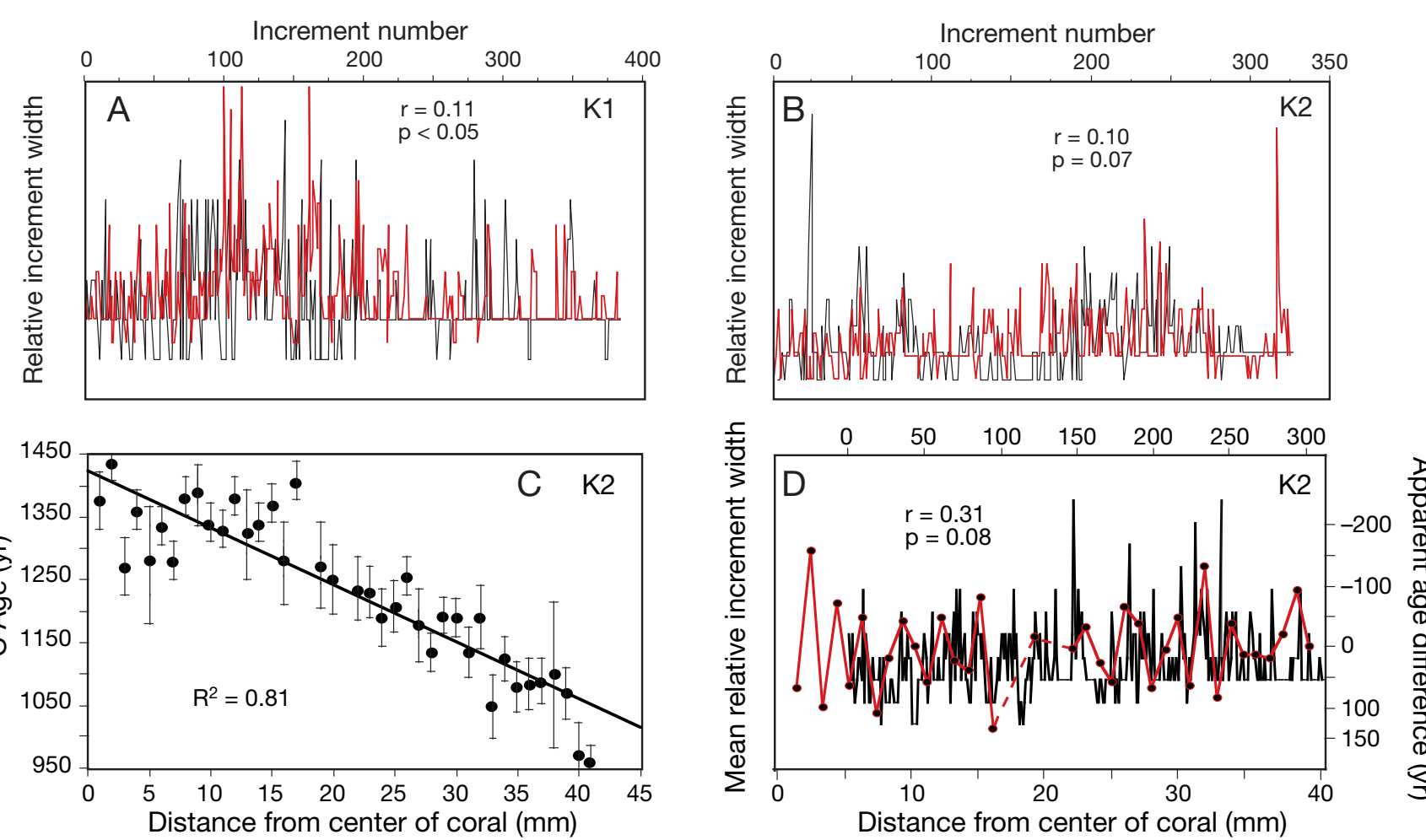

Fig. 5. Keratoisis sp. (A,B) Increment width along 2 radii (black and red lines) in Specimens K1 and K2 (described in Thresher et al. 2004). (C) Radiometric $\left({ }^{14} \mathrm{C}\right)$ age estimates (mean $\pm \mathrm{SD}$ ) for 39 blocks of calcite cut at $1 \mathrm{~mm}$ intervals along the $41 \mathrm{~mm}$ radius of the K2 internode. (D) Ontogenetic variability in mean increment widths in K2 (black line) with age differences between consecutive calcite blocks across the internode (red line), calculated after detrending the age data, using residuals around the linear regression line; dashed: missing data. Correlation calculated after lightly filtering the increment width data, using a 3-point unweighted running mean. Absence of data near the center of the colony due to poor definition

where the coral was collected, and indicate a total colony age of about 360 years and a relatively constant growth rate (linear regression between age and distance across the internode; $r=0.90, p<0.001)$. Scatter about the regression line reflects measurement error (mean SD of the age estimates: $38.4 \mathrm{yr}$ ), variable growth rates and heaving of the water column, which would affect reservoir age. To compare age differences with increment width, the age data were first detrended, by using the residuals around the linear regression line, in order to remove the long-term bias. The comparison of increment width to age differences between adjacent calcite samples is shown in Fig. 5D. There is a reasonable correspondence between the 2 indices of colony growth, with small age differences (i.e. faster growth) tending to coincide with areas of relatively wide increments. The broad match between the 2 indices is verified by a nearly significant correlation $(r=0.31, p=0.08)$, after increment widths are lightly filtered using an unweighted 3-point running mean. An exact match between the 2 assays is unlikely, given the different sections and radii used for the analyses (see Thresher et al. 2007), but the results are consistent with the hypothesis that variability in increment width reflects intra-colony growth rate.

In both specimens, correlations between the trend in average increment widths and $\mathrm{Mg} / \mathrm{Ca}, \mathrm{Sr} / \mathrm{Ca}$ and $\mathrm{S} / \mathrm{Ca}$ ratios were wholly non-significant. In both, however, there was a weak $(p<0.1)$ tendency for increment width to correlate negatively with $\mathrm{P} / \mathrm{Ca}$ ratio. In contrast, increment width in both specimens correlated significantly with Ca weight-fraction (K1: $\mathrm{r}=0.40, \mathrm{p}<$ 0.001; K2: $\mathrm{r}=0.18, \mathrm{p}<0.01$ ) (Fig. 6A,B) and $\mathrm{P} / \mathrm{S}$ ratio (K1: $\mathrm{r}=0.22, \mathrm{p}<0.005 ; \mathrm{K} 2: \mathrm{r}=0.17, \mathrm{p}<0.01$ ) (Fig. 6C,D). As predicted, correlations between Ca weight-fraction and $\mathrm{P} / \mathrm{S}$ ratio were also significant and negative, if noisy, in both specimens (K1: $\mathrm{r}=0.13, \mathrm{p}<$ 0.05 ; K2: $r=0.11, p<0.05$ ) (Fig. 6E,F). In K2, the correlation was significant only after high $\mathrm{Ca}$ weightfractions near the core of the coral were excluded from the analysis. There was a similar discrepancy at the core of K1, as well as a discrepancy in the same specimen between increment width and both $\mathrm{Ca}$ and P/S ratio. Multiple regression analysis indicates that the principal determinant of ontogenetic variability in $\mathrm{P} / \mathrm{S}$ ratio in both specimens is $\mathrm{P} / \mathrm{Ca}$, which accounts for $95 \%$ of the variability in $\mathrm{K} 1$ and $77 \%$ in $\mathrm{K} 2$. 

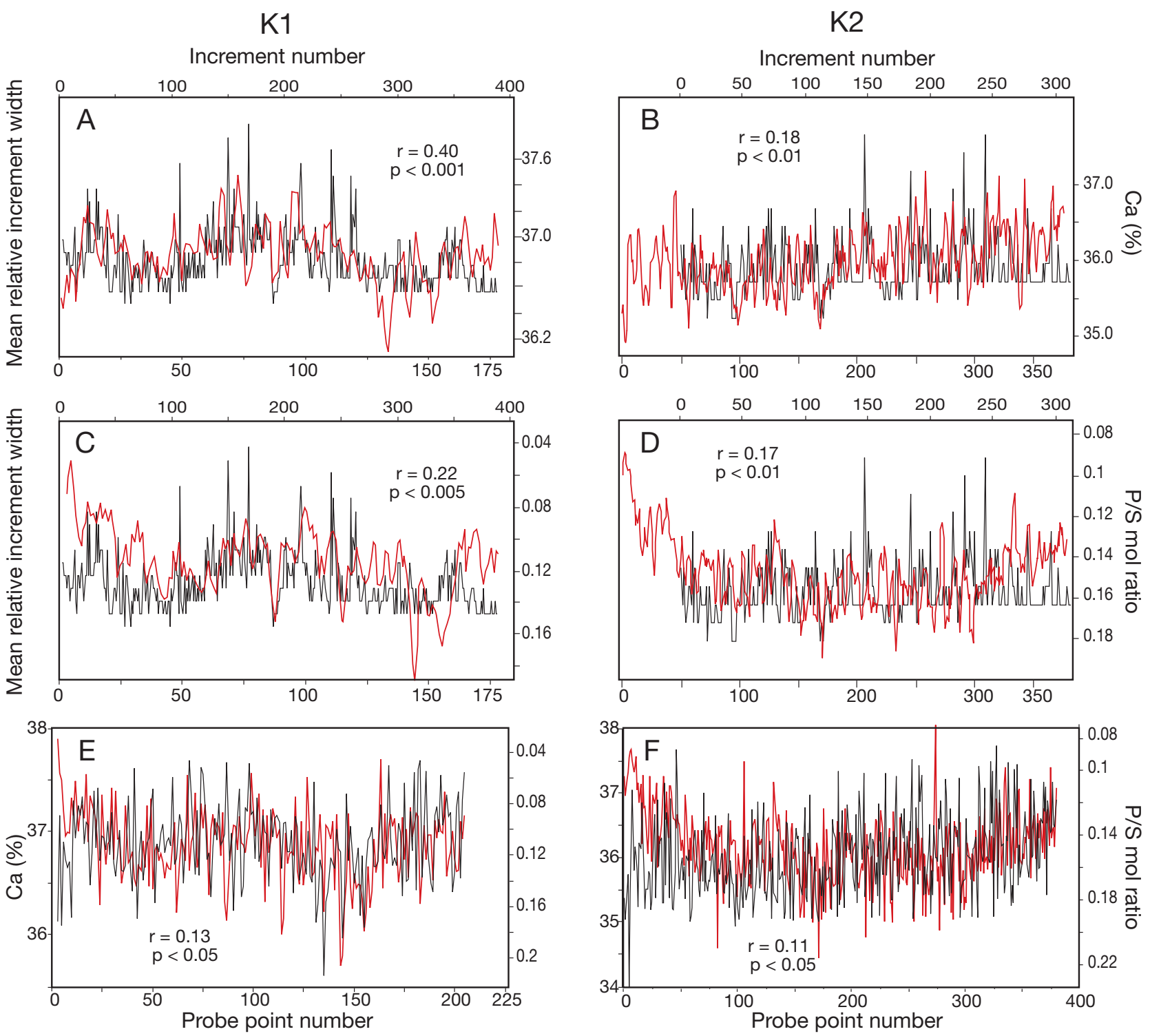

Fig. 6. Keratoisis sp. Ontogenetic variability in increment width vs. Ca weight-fractions and P/S ratios in Specimens K1 and K2. $(\mathrm{A}, \mathrm{B})$ Mean trend of ontogenetic changes in increment width (black line) vs. radial variability in the Ca weight-fractions (red lines). (C,D) Mean trend of ontogenetic changes in increment width (black lines) vs. radial variability in the P/S ratios (red lines). (E,F) Ontogenetic variability in Ca weight-fractions (black lines) vs. P/S ratios (red lines). P/S ratios are plotted inversely. Elemental data smoothed using a 3-point unweighted running mean

\section{DISCUSSION}

The strength of the inferences that can be drawn from the present study is constrained by the small sample sizes and consequent risks of spurious correlations, particularly in multiple regression analyses. There are also possible problems that arise from uncertain data quality: the depth at which some samples were collected is not well specified, temperature estimates may be biased by uneven seasonal sampling and there are measurement errors inherent in each aging method.
These sources of possible error constrain the amount of variance likely to be explained by any analysis and require cautious interpretation of the results. Nonetheless, a conclusion that temperature is a major determinant of growth rate in bamboo corals appears robust. For 23 specimens of bamboo coral, collected at sites ranging from Antarctica to Hawaii, water temperature alone accounts for more than half of the differences among colonies in lifetime mean growth rate. In that regard, these deep-water corals do not differ from most poikilotherms, in which temperature plays a major role 
in determining physiological rates. Multiple regression analysis suggests that the correlation between growth rate and temperature accounts for the weaker association between growth rate and collection depth. Roberts et al. (2009) noted a similar correlation between depth and growth rate for cold-water corals in general, and for scleractinians and Corallium spp. (a gorgonian) in particular. They hypothesize that the depth effect reflects a lower availability of surface-derived food for deeper dwelling specimens, but the similarity of the scatterplots of growth rate against depth for isidids and the taxa pulled together by Roberts et al. (2009) suggest that temperature may be important for the latter as well. The strong effect of temperature on growth rates in bamboo corals implies that the effects of other factors, such as food limitation, could often be difficult to detect, particularly at the upper and lower temperature limits examined in the present study. Growth rates that apparently approach asymptotes at temperatures $<\sim 2$ and $>5^{\circ} \mathrm{C}$ suggest physiological constraints on the corals associated with, on the one hand, a minimum growth rate required to survive and, on the other, an as yet unidentified biochemical factor that limits calcification rates at high temperatures.

Between these extremes, growth rate varies widely at a given temperature, which probably reflects a combination of measurement error, alternative life-history strategies and the effects of factors other than temperature on growth. Part of this variability could have a geographic basis. Data are too sparse to draw strong conclusions, but thus far isidids from the NE Pacific tend to grow faster relative to ambient temperature than those in other regions. The cause of this difference is not clear, but one possibility is that it reflects differences in food availability. Surface productivity tends to be high in the NE Pacific relative to most other parts of the world's oceans (Koblentz-Mishke et al. 1970), and isotopic evidence indicates that bamboo corals feed on suspended matter derived from surface production (Roark et al. 2005, Sherwood et al. 2009, in this Theme Section). However, surface productivity also tends to be high in the NW Atlantic, for which colony growth rates are close to or even slightly lower than predicted. As the NE Pacific growth rate estimates are from 2 different research groups using different aging methods (radiocarbon and U-series analyses), a bias in age estimates as an explanation for the apparent regional difference is unlikely.

Investigating the factors that affect growth rate would be easier if there were a proxy for it in the coral's skeleton. Sr/Ca has previously been suggested to vary with growth rate in gorgonians (Weinbauer et al. 2000, Roark et al. 2005), but the present analysis does not support this hypothesis. Within colonies, growth rate as measured by changes in increment width correlates positively with Ca weight-fractions and negatively with an index of the relative amount of EDTA-insoluble organic material present-P/S ratio. Antiphasic variability in the deposition rates of $\mathrm{Ca}$ and skeletal organics has previously been documented in other biogenic carbonates (e.g. Rhoads \& Lutz 1980, Mugiya 1987) and linked to growth rate (low Ca and high organics during periods of little or no growth, e.g. Casselman 1982). A similar mechanism may account for the ontogenetic correlations in K1 and K2. This hypothesis is partly consistent with an ultrastructural study of Keratoisis by Noe \& Dullo (2006), which reports 2 primary crystal structures in the internodes: 'fibre bundles', which are similar to the elongate crystals formed during periods of fast growth in other biogenic carbonates (Lowenstam \& Weiner 1989), and granular crystals which, they suggest, develop under low growth conditions. Studies of other taxa (e.g. Mugiya 1987) indicate the fast-growth, elongate crystals are relatively high in $\mathrm{Ca}$ and low in organic content, which is consistent with the hypothesis above. However, Noe \& Dullo (2006) suggest the opposite in Keratoisis (fibrous bundles high in organic content, as opposed to the granular crystals, which they characterise as having a 'poverty of organic material'). The apparent inconsistency might be resolved by high resolution spatial mapping of element weight-fractions across regions of different crystal structure and growth rates, similar to that by Gagnon et al. (2007) in the deep-water scleractinian Desmophyllum dianthus.

In contrast to intra-colony variability, none of the potential proxies examined correlate highly with differences in growth rate among colonies. The highest correlate is colony mean $\mathrm{Ca}$ weight-fraction, which tends to be higher in faster growing colonies after effects of depth are accounted for. The observation is consistent with the results of the intra-colony analyses, but the weakness of the association and the lack of any parallel correlation for $\mathrm{P} / \mathrm{S}$ ratios suggest that any growth rate effects are obscured by other factors that affect internode composition. For P/S ratios, 2 factors may be important: (1) Difficulties in standardising $P$ measurements across specimens could be contributing to the poor correlation. Average P weight-fractions are low relative to the element's minimum detection limits on the electron microprobe. As a result, heterogeneity in the apatite used to standardise measurements across specimens could disproportionately affect estimates of inter-colony differences and perhaps obscure biologically meaningful signals. Standardisation errors would not affect intra-colony comparisons, as all measurements across the coral are done during the same analysis series. (2) Recent work on deep-water scleractinians suggests that skeletal $\mathrm{P} / \mathrm{Ca}$ ratios, variability of which dominates the P/S signal in isidids, are sensitive to 
environmental phosphorus concentrations (Montagna et al. 2006). If so, and if also applicable to bamboo corals, the large spatial heterogeneity of $\mathrm{P}$ in seawater could limit the value of the index for comparing wholecolony growth rates. Other elements that are principally or wholly found in the organic fraction, such as boron (Thresher et al. unpubl. data), might prove to be useful alternatives to the P/S ratio, though they demand higher analytic resolution, due to their low absolute weight-fractions.

Acknowledgements. I thank K. Evans for measuring the growth increments in $\mathrm{K} 1$ and $\mathrm{K} 2, \mathrm{~A}$. Thresher for assistance with the CARS database, S. Fallon for the radiocarbon age data, O. Sherwood for data for North Atlantic isidids, valuable discussion about bamboo coral ecology and composition and comments on an earlier draft of the manuscript, 3 anonymous referees for comments and H. Neil and D. Tracey for organising the Fourth International Symposium on Deep-sea Corals (Wellington, NZ, 2008), where some of the ideas presented in this paper were discussed. This work was supported by the CSIRO Wealth from Oceans and Climate Adaptation Flagship Programs.

\section{LITERATURE CITED}

Andrews AH, Cordes EE, Mahoney MM, Munk K, Coale KH, Cailliet GM, Heifetz J (2002) Age, growth and radiometric age validation of a deep-sea, habitat-forming gorgonian (Primnoa resedaeformis) from the Gulf of Alaska. Hydrobiologia 471:101-110

Andrews AH, Lundstrom CC, Caillet GM, DeVolgelaere AP (2007) Investigations of bamboo coral age and growth from Davidson Seamount. Tech Rep Monterey Bay National Marine Sanctuary, Monterey, CA

Casselman JM (1982) Age and growth assessment of fish from their calcified structures: techniques and tools. NOAA Tech Rep 8:1-17

France SC (2007) Genetic analysis of bamboo corals (Cnidaria: Octocorallia: Isididae): Does lack of colony branching distinguish Lepidisis from Keratoisis? Bull Mar Sci 81:323-333

Freiwald A, Roberts JM (2005) Cold-water corals and ecosystems. Springer-Verlag, Berlin

Gagnon AC, Adkins JF, Fernandez DP, Robinson LF (2007) $\mathrm{Sr} / \mathrm{Ca}$ and $\mathrm{Mg} / \mathrm{Ca}$ vital effects correlated with skeletal architecture in a scleractinian deep-sea coral and the role of Rayleigh fractionation. Earth Planet Sci Lett 261:280-295

Grigg RW (1974) Growth rings: annual periodicity in two gorgonian corals. Ecology 55:876-881

Gunn J, Harrowfield I, Proctor CH, Thresher RE (1992) Wavelength dispersive electron probe microanalysis of calcified tissues in fishes: analysis of techniques appropriate to studies of age and stock discrimination. J Exp Mar Biol Ecol 158:1-36

Heikoop JM, Hickmott DD, Risk MJ, Shearer CK, Atudorei V (2002) Potential climate signals from the deep-sea gorgonian coral Primnoa resedaeformis. Hydrobiologia 471: $117-124$

Koblentz-Mishke OJ, Volkovinsky VV, Kabanova YG (1970) Plankton primary productivity of the world ocean. In:
Wooster WS (ed) Scientific exploration of the South Pacific. Natl Acad Sci, Washington, DC, p 183-193

Krieger KL, Wing BL (2002) Megafauna associations with deepwater corals (Primnoa spp.) in the Gulf of Alaska. Hydrobiologia 471:83-90

Lowenstam HA, Weiner S (1989) On biomineralization. Oxford University Press, New York

Montagna P, McCulloch M, Taviani M, Mazzoli C, Vendrell B (2006) Phosphorus in cold-water corals as a proxy for seawater nutrient chemistry. Science 312:1788-1791

Mugiya Y (1987) Phase difference between calcification and organic matrix formation in the diurnal growth of otoliths in the rainbow trout, Salmo gairdneri. Fish Bull 85: 395-401

> Noe SU, Dullo WC (2006) Skeletal morphogenesis and growth mode of modern and fossil deep-water isidid gorgonians (Octocorallia) in the west Pacific (New Zealand and Sea of Okhotsk). Coral Reefs 25:303-320

Rhoads DC, Lutz RA (eds) (1980) Skeletal growth of aquatic organisms. Plenum Press, New York

- Ridgway KR, Dunn JR, Wilkin JL (2002) Ocean interpolation by four-dimensional least squares: application to the waters around Australia. J Atmos Ocean Technol 19: $1357-1375$

> Roark EB, Guilderson TP, Flood-Page S, Dunbar BD, Ingram BL, Fallon SJ, McCulloch M (2005) Radiocarbon based ages and growth rates for bamboo corals from the Gulf of Alaska. Geophys Res Lett 32:L04606

Roberts JM, Wheeler A, Freiwald A, Cairns S (2009) Coldwater corals. Cambridge University Press, New York

Sherwood OA, Edinger EN (2009) Ages and growth rates of some deep-sea gorgonian and antipatharian corals of Newfoundland and Labrador. Can J Fish Aquat Sci 66: $142-152$

Sherwood OA, Scott DB, Risk MJ (2006) Late Holocene radiocarbon and aspartic acid racemization dating of deep-sea octocorals. Geochim Cosmochim Acta 70:2806-2814

Sherwood OA, Thresher RE, Fallon SJ, Davies DM, Trull TW (2009) Multi-century time-series of ${ }^{15} \mathrm{~N}$ and ${ }^{14} \mathrm{C}$ in bamboo corals from deep Tasmanian seamounts: evidence for stable oceanographic conditions. Mar Ecol Prog Ser 397: 209-218

Thresher RE, Rintoul SR, Koslow JA, Weidman C, Adkins J, Proctor C (2004) Oceanic evidence of climate change in southern Australia over the last three centuries. Geophys Res Lett 31:L07212

Thresher RE, MacRae CM, Wilson NC, Gurney R (2007) Environmental effects on the skeletal composition of deepwater gorgonians (Keratoisis spp.; Isididae). Bull Mar Sci 81:409-422

Thresher RE, MacRae CM, Wilson NC, Fallon S (2009) Feasibility of age determination of deep-water bamboo corals (Gorgonacea; Isididae) from annual cycles in skeletal composition. Deep-Sea Res I 56:442-449

Tracey DM, Neil H, Marriott P, Andrews AH, Calliet GM, Sanchez JA (2007) Age and growth of two genera of deepsea bamboo corals (family Isididae) in New Zealand waters. Bull Mar Sci 81:393-408

Vogel JS, Nelson DE, Southron JR (1987) ${ }^{14} \mathrm{C}$ background levels in an accelerator mass spectrometry system. Radiocarbon 29:323-333

Weinbauer MG, Brandstatter F, Velimirov B (2000) On the potential use of magnesium and strontium concentrations as ecological indicators in the calcite skeleton of the red coral (Corallium rubrum). Mar Biol 137:801-809 